UDC 005.35

DOI https://doi.org/10.26661/hst-2019-1-78-12

\title{
DEVELOPING CORPORATE MANAGEMENT TO IMPROVE THE QUALITY OF CUSTOMER SERVICE
}

\author{
(C) BIRUTE் PETROŠIENE \\ Marijampole college (Marijampole Lithuania) \\ E-mail: bir.petr@mkolegija.lt, ORCID: 0000-0002-5160-8249 \\ (C) RÜTA IVANAUSKIENE \\ Marijampole college (Marijampole Lithuania) \\ E-mail rut.ivan@mkolegija.lt, ORCID: 0000-0002-6877-6003 \\ Marijampoles College V. Kudirkos g. 61 Marijampole Lithuania
}

\begin{abstract}
In today's society, all companies face constant changes that cause unrest within the company. The stimuli that have the greatest impact on change are unexpected fluctuations that usually occur from the outside environment. One of the priority factors that has strong impact on the success of the company is the users of the goods or services provided. Customer satisfaction is considered to be one of the most important factors in determining a company's success [14]. Companies that give priority to management oriented towards the users of the provided services (goods) have the greatest prospects and advantage in other respects. In the context of corporate dependence on consumers, it is important to ensure a high quality and fully refined customer service process while improving corporate management. The widespread choice of corporate management methods and alternatives to their improvement creates opportunities for companies that, unfortunately, are sometimes far from being one of the most important factors in a company's profitability and authority in the market - its customers. The energy supplier is AB "Energijos Skirstymo Operatorius" (Energy Distribution Operator) (hereinafter - ESO AB), which has more than 1.6 million customers, and is the dominant energy service company in Lithuania. A dominant energy service company often allows itself to make predetermined or unplanned changes in corporate management, regardless of the quality and expectations of consumers' opinion when evaluating the quality of service. For these reasons, scientific, practical, analytical research into customer service quality in public service delivery is particularly relevant and significant. Problem and relevance. One of the most emphasized factors in both the theoretical and practical activities of a company in providing services is the quality of customer service. Continuous processes to improve corporate management regardless of customer expectations create barriers to customer service quality. The discrepancy between experienced and expected quality in customer service creates deficiencies in customer service, leading to resentment, mistrust and frustration with the service users, and creates a negative image of the company nationally and internationally. For these reasons, the practical and theoretical question of whether the ongoing reorganization of the management of the energy sector company in the field of public service provision is based on the improvement of customer service remains a challenge. The aim of the research - to evaluate the improvement of the management of the company oriented to the quality of customer service in accordance with the theoretical and practical provisions of management. The object of the research is the customer service system of AB ESO. Research objectives: To identify the interrelationships between customer service and quality management aimed at improving corporate management; after analyzing the application of quality management in enterprises to present the main and common elements of management improvement. To describe the peculiarities of the management and customer service process of ESO AB. To evaluate the experienced and
\end{abstract}

(C) Birutè Petrošiene \& Rūta Ivanauskiene, 2019 
expected quality of customer service of ESO $\mathrm{AB}$, on the basis of which to research the opinion of the company's representatives on the management elements to be improved.

Research methods - analysis of scientific literature; document analysis; data analysis; questionnaire; graphic representation

Keywords: customer, quality of service, human resources, corporate management, strategy, prestige.

\section{CUSTOMER SERVICE QUALITY CONCEPT AND} ASSESSMENT METHODS

In today's scientific literature, customer service is an integral component of both the service and goods sectors. Over the last few decades, the attitude towards the customer and the influence he has been undergoing has been constantly evolving until finally he has begun to exert an increasing influence on the business operations of the company, the strategy.

Customers and their service can be attributed not only to low-control environmental factors [8], but can also be used as a resource for businesses to provide better and high quality services. In this case, it is important to identify the customer and their service as an external factor or resource contributing to the value creation process. By interacting directly with each other, the client and the company create a collaborative partnership that is characterized by dialogue. In the common sphere, the on-going service process between the company providing the service and the customer enables both parties of the action to better understand the mutual benefits. Customer involvement brings economic, relational and psychological benefits to both employees [23] and increases the productivity and efficiency of the company and encourages the company to continually improve management. According to the researchers, the antecedent of customer service focuses on company-customer relationships, customer knowledge and motivation [23]. Quality customer service can be defined as the internal and external resources of a company [6], in this case customer interaction with each other, creating added value for the company while strengthening customer relationships. Customer retention is important for all companies, regardless of their type and size [3].

Customer service in service companies can be associated with evaluating customer experiences from a service quality perspective. This insight reveals the broader content of the customer service concept by incorporating an experience

management element that combines elements such as consumer emotion, satisfaction, cognitive and emotional values, memory, recommendation exchange, and more [2] what is necessary for quality assurance. It is noticeable that the very definition of customer service in its content is related to quality, which is revealed in particular through continuous analysis of the customer, which subsequently influences certain changes in the company.

Nowadays, in times of economic toughness and increasing competition, 
quality of customer satisfaction in customer service is essential as it increases customer loyalty $[9,11,12]$.

Quality can be measured from several different disciplines such as: economics, marketing, psychology or performance research [4], so these factors are important in customer service: customer recognition; courtesy: elementary polite communication with the client, including words such as: please and thank you; delivering service on time: most clients are tolerant of waiting time if there are good reasons such as: there are no free staff available to serve because they are serving other customers, but if the customer is forced to wait without reason, for example, employees communicate with each other and pay no attention to the waiting customers, then the perceived concept of service quality is affected and leads to customer

dissatisfaction;

professionalism: the recipient of the service expects to have a variety of skills such as: quick and detailed answers to his / her questions and services that match expectations; empathy: the willingness of consumers to understand, especially when clients are confronted with a language barrier or some disability that reduces their communication effectiveness; patience: the customer may be dissatisfied with the service the company provides and may cause the customer annoyance. Enthusiastic service: customers come to the company for one reason to meet their needs. Providing additional services and information will help the company ensure a positive customer service experience. In order to increase the value, prestige and competitive advantage of the company, the customer service must be of high quality, taking into account the key elements contributing to the quality of customer service.

\section{STAGES OF DEVELOPING} CORPORATE MANAGEMENT TO IMPROVE THE QUALITY OF CUSTOMER SERVICE

Corporate management, as well as its improvement, is a process that consists of these stages: planning, organizing, management and controlling activities using financial, human, material and immaterial resources [20]. Customers are one of the resources of a company [8] and therefore an important component contributing to management, especially its improvement. With this in mind, it is important to include it in improving corporate management. Management improvement is a kind of response to ongoing changes in the environment, and in a general sense, management improvement can be described as a change within the company [17]. The main changes affecting management changes can be identified from external environment, management, internal environment and company culture [17].

Taking into account that in this case the improvement of corporate management is based on consumer opinion and experience, one of the first stages in improving corporate management focused on the quality of customer service is to capture current customer perceptions of services / goods provided and measure service satisfaction [21]. A variety of 
quantitative and qualitative service evaluation methods are used to assess the current situation and provide a more detailed understanding of consumers' views. Stage two: evaluation of the information collected / results of the study [17]. Based on the information received, further steps and sequences of actions are taken internally within the company to improve customer satisfaction through quality management. The company-wide analysis of the customer service process, detailing the gaps in the company management structures, goals, vision, strategy, resource-based interfaces to customer service. Stage three: planning management development by improving customer service quality. The steps of the planning process, in this case directed at managing the company to improve customer service, are referred to as [7]:

1. Initiating planning: managers, stakeholders, senior managers.

2. Assessment of future situation. The aim is to focus on the key factors determining the success of change.

3. Formulating aims with clear goals.

4. Implementation of alternatives: different ways and changes are envisaged to ensure the realization of the goals.

5. Assessment of alternatives: the strengths and weaknesses of the chosen alternatives are examined in the light of the objectives and assumptions made.
6. Choosing the best alternative. A final step on the way forward.

7. Implementation. Prepare and implement a final plan, in this case management development by improving customer service quality, prepare sub-plans and implement them.

It is important to include the involvement of all business units in the planning stage [20] as each level of the company structure can be important. At this level, it is important to evaluate the resources, their scale and nature, their strategy. Taking into account that the planning process has a direct influence on the organization, management and control, it defines clear guidelines for these corporate management functions. Stage four: organization with one of the main goals to create structures for realizing the tasks set during planning [7]. At this level, the distribution of labor, resources, and power is predominant (ibid.). This stage of the corporate management development process is characterized by:

1. Adjustment of operational objectives and strategy;

2. To distribute the goals set among the units of the company;

3 . To clearly define the management functions required to achieve the goals set;

4. To allocate the human resources needed to perform the functions;

5. To select organizational characteristics: distribution of power, number of management levels, etc.;

6. To review structural units for their functions, relationships, rights, responsibilities, and more. 
7. To re-regulate and redefine company characteristics, management activities procedures, information processing, determine interdepartmental activities, management costs, etc. [7].

Stage five: leadership ensuring management improvement. At this level, the employees are motivated and joined for common work, very often motivated by personal goals to achieve corporate goals aimed at management improvement. Leadership is an impact on employees [19] and therefore the role of the manager is significant at this stage of change. Stage six: control of management development by improving customer service quality. At this level it is important to compare the planned and actual state [20]. There are many controls that help you compare actual results such as: measurement, recording, calculation, surveys, and more. The main objective of the control phase is linked to the implementation of management improvement objectives focused on the quality of service to consumers. In this case, it is important for the company to keep track of such indicators as service, quality.

\section{CHANGES OF}

\section{MANAGEMENT ELEMENTS TO IMPROVE THE QUALITY OF CUSTOMER SERVICE}

The retention of service users is particularly relevant in today's competitive and unstable financial market world [13]. It is important to clearly define not only the key phases but also the elements, their changes and the interaction with each other in the process of improving the management of a company aimed at improving the quality of customer service. The following elements are important: external environment (customers) - customers are a factor in the external environment, triggering changes in corporate management that is linked to other elements of the company. It is not always that external environmental factors influence all elements of the company, the stimulus can only be associated with a few elements. The customer plays a major role in the value creation process of the company; vision / mission - the element most often revealing the purpose of the existence of a company. Vision is an idealized concept of expected events and situations and its presentation that gives motivation, confidence [7]. Meanwhile, the mission in the scientific literature can be divided into two perspectives: strategic and cultural [5]. At the company level, vision is the highest measure of mission formation and aims to implement them. These management elements may not always influence the quality of customer service while improving the management of a company, but they often have strong interrelationships; goals - an element based on the results to be achieved and realized [7]. Properly chosen goals will provide more appropriate and clearer conditions for achieving customer service quality. Goals are a very important element in every company and their wrong choice can negatively impact the company's performance and market success; strategy is one of the most important factors for a company, the right choice 
of which equates to the key to success [1]. Companies have little control over macroeconomic changes, but companies that choose a suitable strategy have greater opportunities and flexibility to adapt to changes taking place in the external environment. Customers are one of the factors behind the external environment, so changes in the medium between the company and the consumers are a particular strategy of choice; communication channels that help enter into relations encourage communication influencing loyalty, trust, and satisfaction [10]; company culture - an element of critical importance to a company for faster and more efficient results and an important factor for success [17]; human resources are one of the factors that have continued to play an important role in customer service for decades and in today's society, where more and more talk is being given to the customer, the human factor is becoming even more important.

Human resources and their management are identified as number one determinant of business success in all Western countries as well as in China in the ten-tier system [15]; technologies - Technical systems are the foundation of the company as they enable the company structures to perform operations. Technology is a key element in enabling employees to perform the necessary operations to enhance customer experience [18]. Today, technology systems are of increasing importance to companies, as they are not only a tool for process optimization, but also cost savings for the company; service is the element most commonly expressed through the application of knowledge and skills, or by the act, processes for the benefit of another entity or company [8]. In the customer service process this is an element that, in the minds of consumers, can often be seen as a factor that has been proven to be successful or largely unsatisfactory; processes is a component that includes service upgrades and their continuous improvement [18] that focuses on improving customer service quality. This element combines the links between management and quality, helping to structure the company, the division of tasks between managers and their teams; methods - a management element, the choice of which is usually determined by the particular area. If the main process of improvement is human resource then we will use one of the following methods: motivation methods, methods of application of the pay system, etc., while to anticipate changes in process improvement we will use other methods; structure - a factor closely related to the improvement of corporate management.

Based on the structure there are chosen such elements as: culture, human resources, decision-making period, etc.; management technique - management activity can only be successful if specific knowledge systems and appropriate management techniques are used [22].

Based on the diversity of management elements, it is noticeable that company management as well as management improvement is a 
complex process involving a range of different elements. For a company, the elements are intertwined and complement each other, so most often, when improving management or a particular area of management, several elements are included.

\section{RESEARCH \\ METHODOLOGY}

Based on the literature review, the analysis of customer service process of public supplier AB "Energijos Skirstomojo Operatorius"( Energy Distribution Operator) was carried out in providing electricity services, highlighting key process elements and taking into account the key elements of customer service quality and the main principles of SERVQUAL approach focused on management improvement; there was carried out a quantitative research, the tool of which was questionnaire survey. The main purpose of the quantitative research is to evaluate the quality of customer service of ESO AB. The questionnaire is based on the SERVQUAL approach, which measures customer service on five dimensions: tangibility, reliability, response, certainty and empathy. The questionnaire used a five-point Likert scale range. The reliability of the dimensions is evaluated based on the Cronbach's alpha coefficient.

\begin{tabular}{|c|c|c|}
\hline Dimension & $\begin{array}{c}\text { Experienced quality } \\
\text { (Cronbach's alfa coefficient) }\end{array}$ & $\begin{array}{c}\text { Expectations } \\
\text { (Cronbach's alfa coefficient) }\end{array}$ \\
\hline Tangibility & 0.945 & 0.980 \\
\hline Certainty & 0.937 & 0.974 \\
\hline Reliability & 0.921 & 0.976 \\
\hline Empathy & 0.928 & 0.975 \\
\hline Response & 0.938 & 0.981 \\
\hline
\end{tabular}

Taking into account that the Cronbach's alpha coefficient for all dimensions is bigger than 0.7 , the questionnaire is considered reliable. According to the Paniotto's formula, applying 5\% of error and the reliability of the sample to be $95 \%$, in order for the opinion of the respondents to be representative of the general population, it is necessary to interview 400 electricity consumers who were interviewed during the survey, and therefore it is considered that a representative sample was composed.

Based on the results of the questionnaire, a qualitative study was conducted to hear the expert's assessment of the key elements of management in a company with the greatest impact on customer service. The selection of experts shall be based on the level of competence of the staff and their experience in meeting customer needs

\section{RESEARCH RESULTS}

Results of questionnaire survey.

Tangibility dimension. According to the survey data, it is seen that both business (4.21) and private (4.26) customers expressed the highest expectations for the neat appearance of the employees, whose experience was higher than expected: private -4.45 , business -4.62 . Based on the views expressed by consumers regarding the company's advertising, the perceived quality rating between 
business (3.92) and private (3.82) customers was below expectations. In terms of customer service quality of $\mathrm{ESO} A B$, the quality of business customers (3.74) was above expectations (3.36), while the quality of private customers (3.88) was below expectations (3.97). Meanwhile, the satisfaction of customer service centers look for business (4.23), private (4.17) exceeded expectations: business (4.15), private (4.10) (see Figure

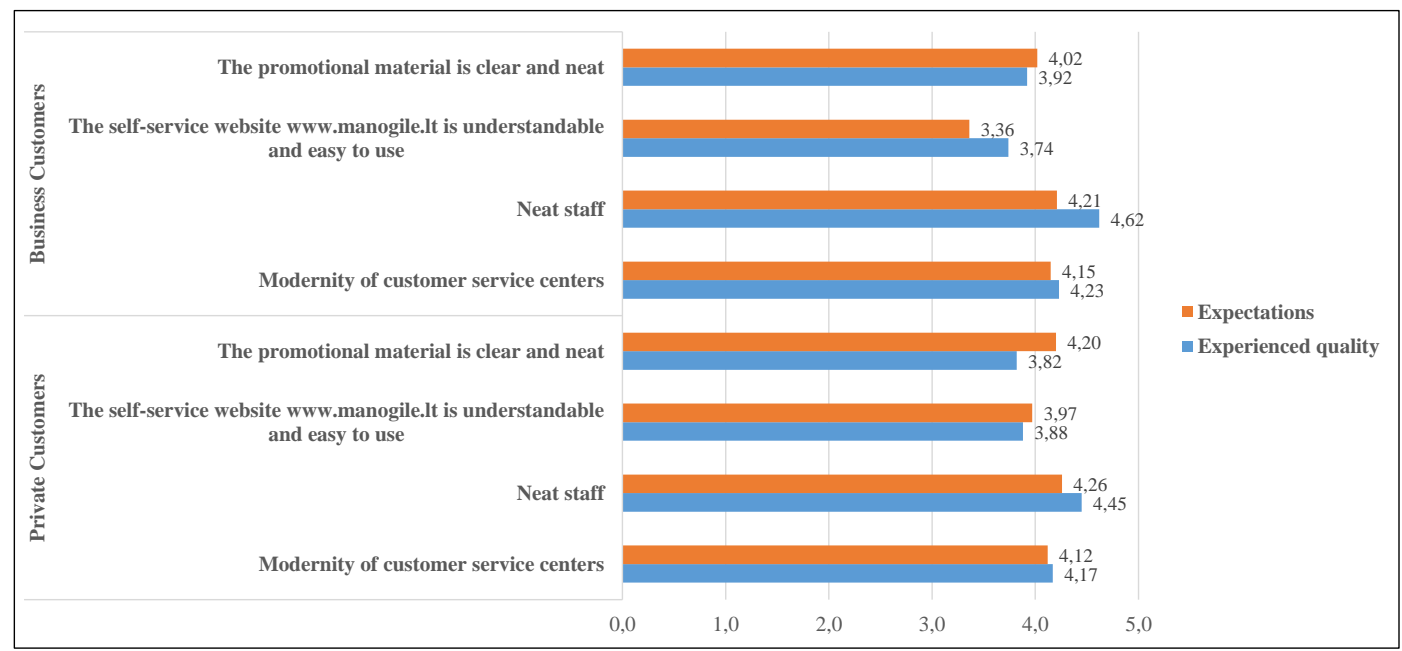

Figure 1. Tangibility dimension from the point of view of business and private customers

Reliability dimension. It provides consumer opinion on the reliability of customer service through the measurement of sub-dimensions such as: response to individual needs, delivery of services at promised times, etc. (see Figure 2).

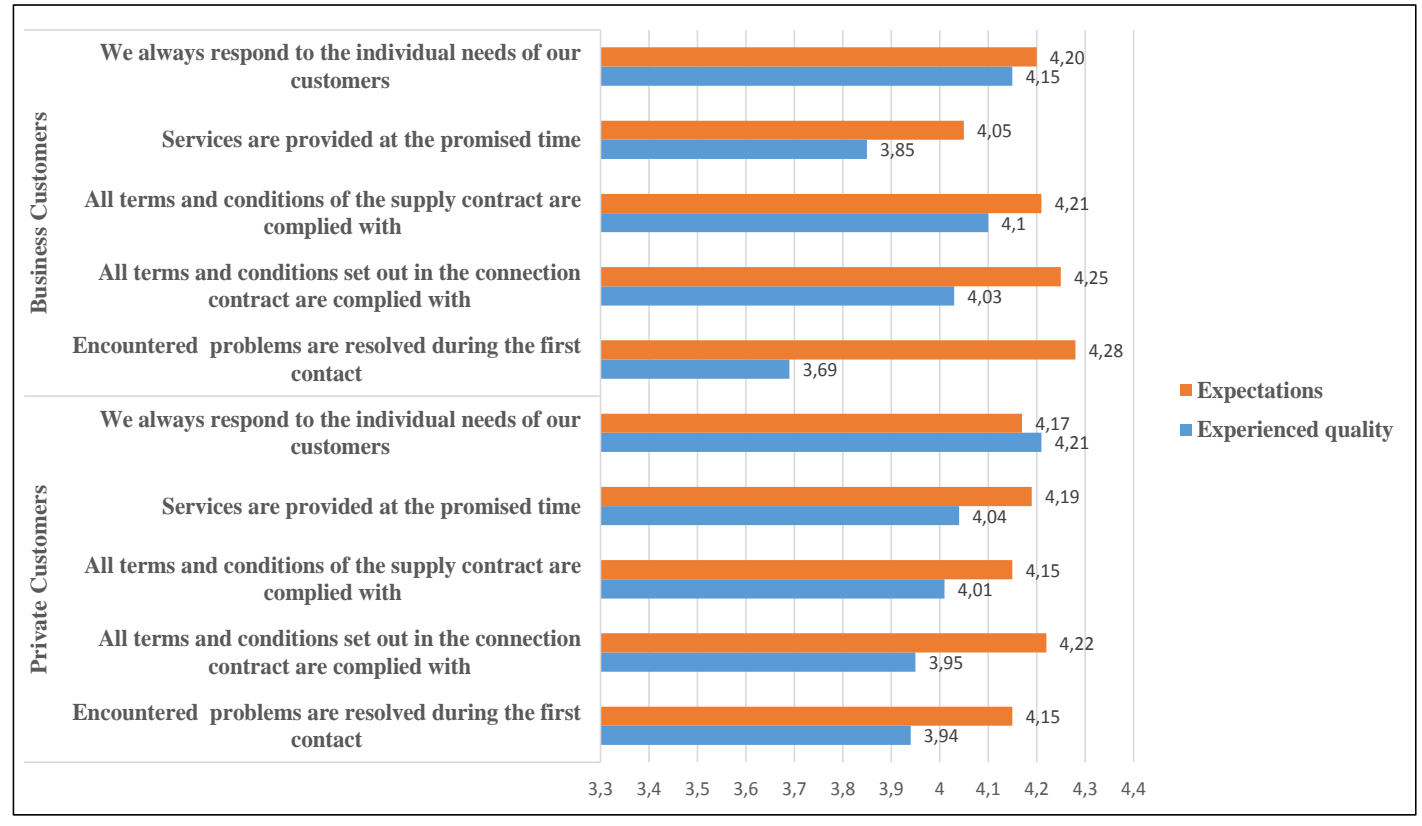

Figure 2. Reliability dimension from the point of view of business and private customers 
The opinion expressed by the business customer reveals that when assessing reliability none of the subdimensions provided met consumer expectations. Business customers expected the company to always respond to individual needs (4.20), but the quality experienced was lower (4.15). Also, the service provided at the promised time did not match the expected situation and varied by 0.2 . There is a big gap between the quality obtained (3.69) and the expectation (4.28) in order to solve the problem in the first contact. Respondents representing business stated that the terms and conditions of both connection and supply were often not met in the company contracts, they expected that the terms and conditions in the connection contract would be met (4.25), but the fact was lower (4.03), expectation of terms and conditions (4.21) was higher than quality experienced (4.10). When analyzing the opinion of private customers, it is noticeable that the experienced quality (4.21) while the company responded to consumers 'individual needs exceeded the respondents' expectations (4.17). The quality fact of the remaining subdimensions was less than expected: the services are expected to be provided at the promised time (4.19), the quality experienced (3.85); expectation of compliance with all terms and conditions of connection contract (4.22), expected quality (3.95), expectation of compliance with all terms and conditions of supply contract (4.15), experienced quality (4.01) ); the problems encountered are expected to be resolved during the first contact (4.15) and the quality experienced is 3.94.

Response dimension. The purpose of this dimension was to pay more attention to the company's human resources, which is constantly emphasized in the social responsibility reports of the jointstock company "Energijos Skirstymo Operatorius" (Energy Distribution Operator). There is relevance of the views expressed by private and business clients in evaluating response sub-dimensions. Both the business and the private sector representatives state that the experienced quality of smooth and fast actions of the staff (business customers - 4.08; private customers - 4.14) exceed expectations (business customers - 4, private customers - 3.91). In terms of employee response, business customers 'expectations (3.93) were lower than the quality received (3.93), and the private customers' ${ }^{6}$ expressed opinion on perceived quality was in line with the expected (4.03). According to the response dimension assessment, the views expressed by both business and private customers revealed that the expressed willingness of employees to help (business customers - 4.07; private 4.12) was lower than the respondents' expectations (business representatives 4.34, private - 4.34). Regarding the fourth statement - information provided by the staff, the experienced quality of business customers (4.13) was lower than expectations (4.23), the opinion of the representatives of private customers agreed with the business, and the experienced quality 
assessment (4.16) was lower than expected $(4,34)$ (see Figure 3).

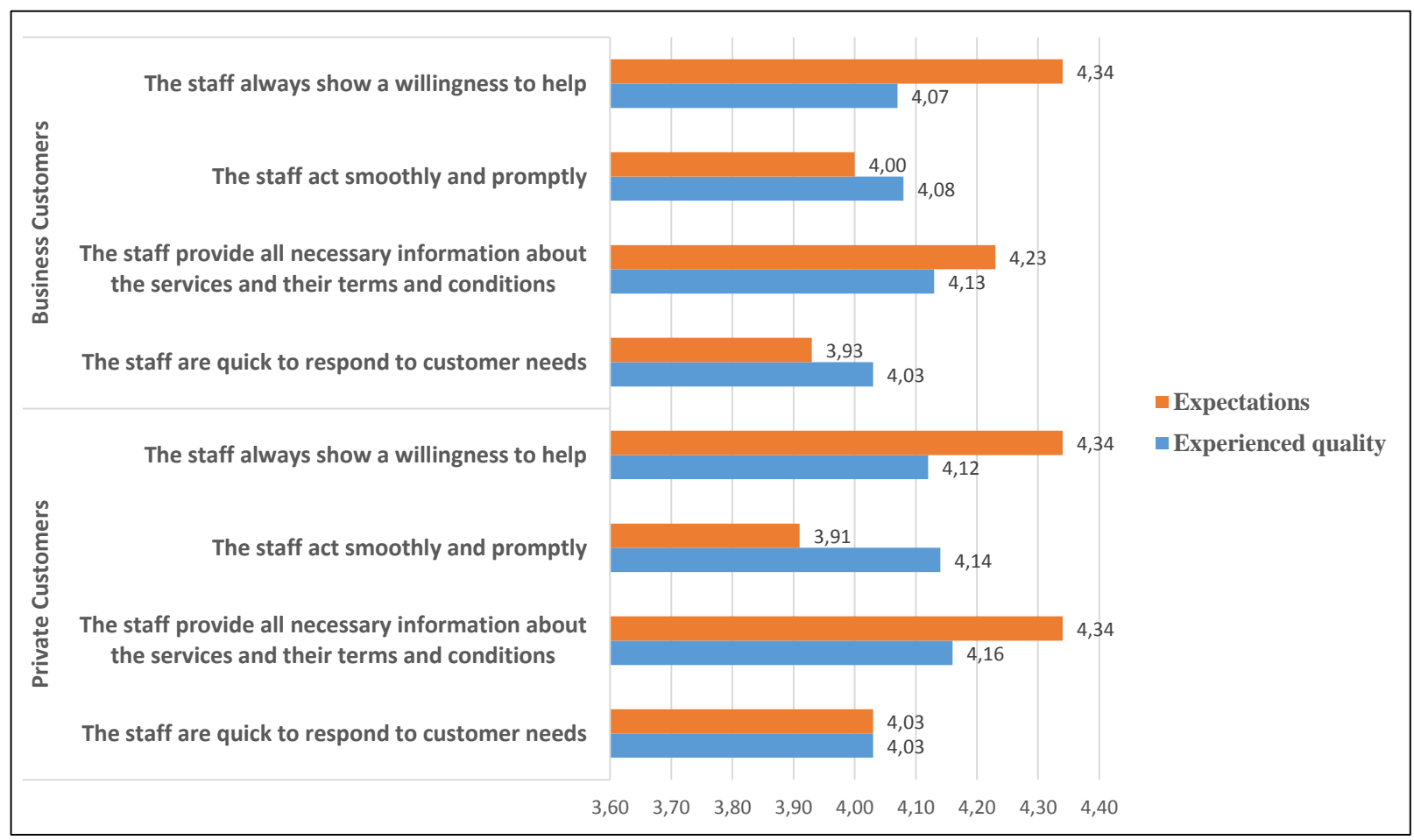

Figure 3. Response dimension from the point of view of business and private customers

Certainty dimension. Taking into account that the service is inherently intangible for the purpose of measuring the certainty of customer service quality, the main subject matter is the employees. Service personnel are an integral part of customer service for the electricity service with respect to the company, which is responsible for providing a quality service to the customer (see Figure 4). A closer examination of the relationship between experienced and expected quality with respect to business customers it is revealed that the amount of information provided by the company's employees was lower (4.1) than expected (4.15). According to the representatives of the companies, the courtesy and reliability of the employees was lower (3.98) than the expectations (4.36), the expectations of the customers (4.34) regarding the qualification of the staff were higher than the experienced quality (4.34). Assessing the competence and knowledge of employees, business customers stated that the quality experienced (3.92) was lower than expected (4.08). 


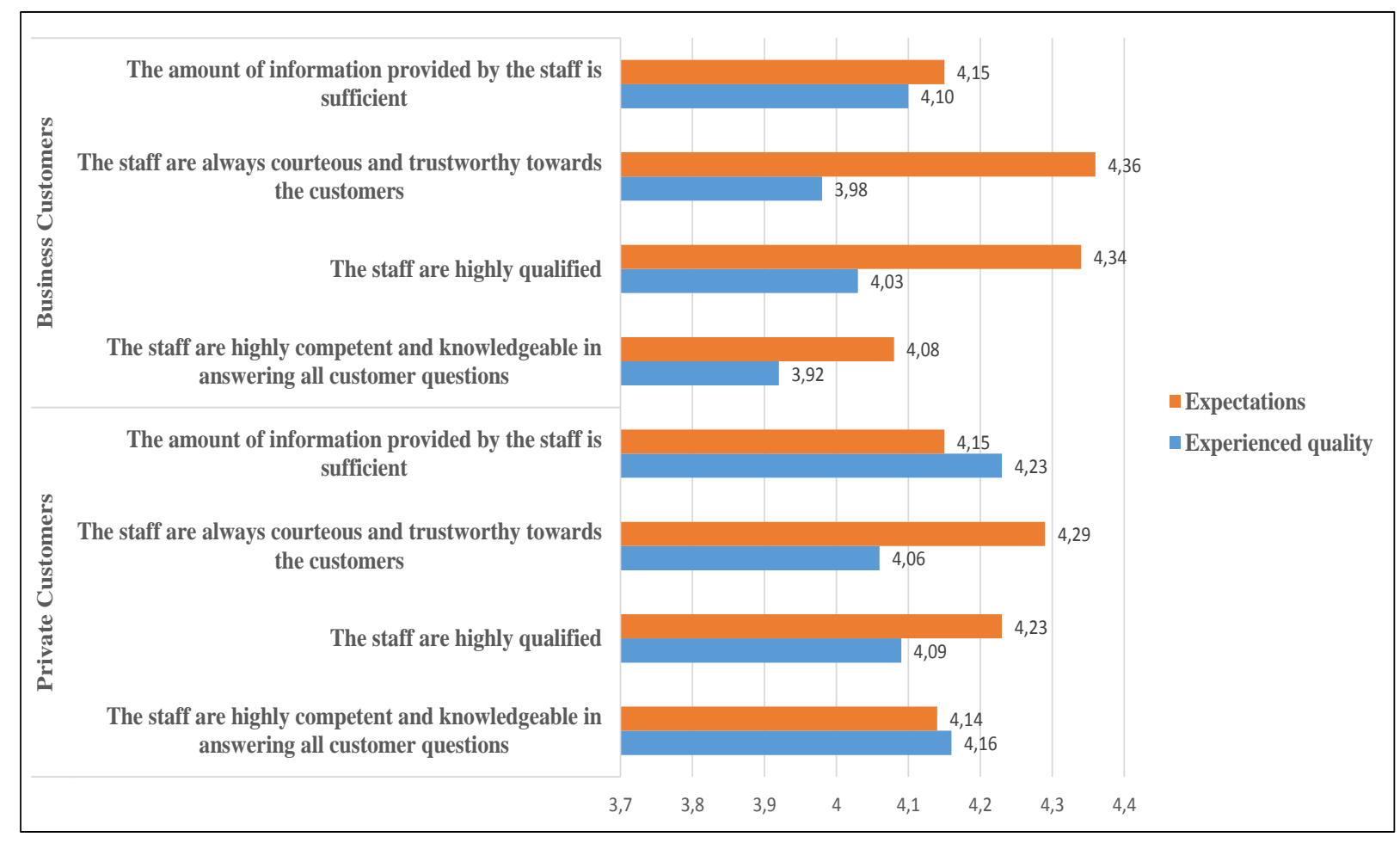

Figure 4. Certainty dimension from the point of view of business and private customers

According to the opinion of private customers, it was distinguished from business customers in terms of the quality of information received from ESO $\mathrm{AB}$ employees (4.23) and exceeds expectations (4.15). Also, the competence and knowledge of the representatives of the company regarding the experienced quality of private customers (4.16) is better than expected (4.14). In the course of the survey, private customers when expressing their opinion agree with business representatives about the lack of competence of the employees, which is explained by the difference between experienced (4.09) and expected (4.23) quality, as well as not always expected (4.29) and experienced $(4,06)$ courtesy and credibility on the part of the staff.
Empathy dimension. The primary purpose of evaluating this dimension with respect to the company represented by the service staff is to assess whether the company is able to establish and maintain communication with the customer through attentiveness, convenient working hours, specific needs, and other areas (see Figure 5).

After evaluating the opinion of business customers, we conclude that the experienced quality measuring the empathy dimension across all subdimensions exceeds or corresponds with the expectations of the respondents. The greatest difference between the experienced quality (4.02) and the expectations (3.95) is particularly pronounced in the staff perception of the specific needs of the business customers. It is noticeable that the experienced quality in relation 
to the renewal of working hours and service offers compared to the expectations of business representatives is similar and differs by $\sim 0.07$ points. When looking at the results of the opinion of private customers, it is seen that the situation is radically different from that of business. Among private respondents, there is a marked difference between the experienced quality (4.10) and the expectations (3.93) when the staff perceive the specific needs.

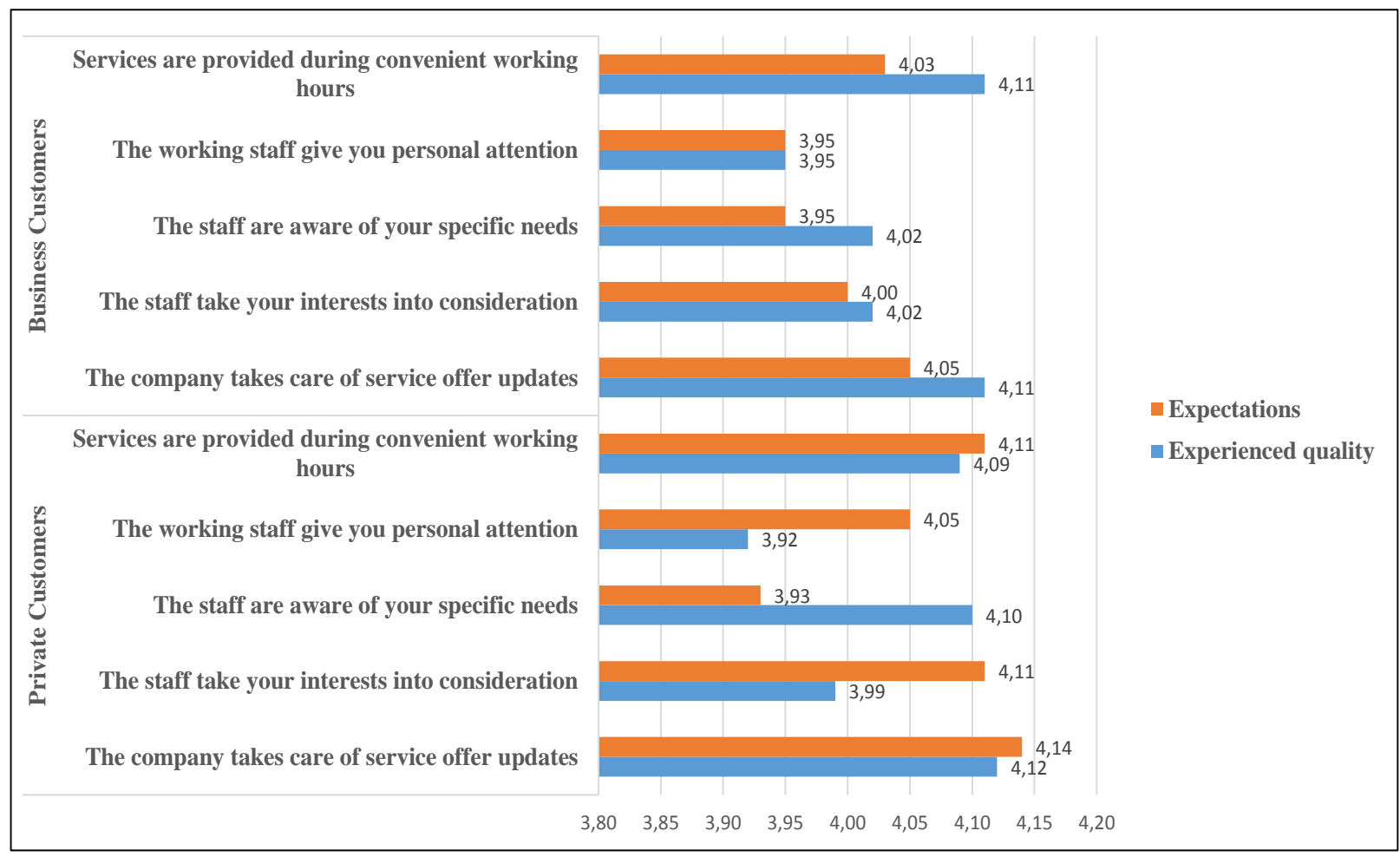

Figure 5. Empathy dimension from the point of view of business and private customers

The experienced quality of the remaining sub-dimensions according to private consumers is lower than expected, this is felt when measuring the employee consideration and concern for consumer interests, when the experienced quality is 0.12 points and the personal attention received from the employees is 0.13 lower than desired.

SUMMARY OF THE QUANTITATIVE AND QUALITATIVE STUDY
1. The overall assessment of customer service quality is below consumer expectations. Particularly when assessing the quality of customer service, there is a gap between private and business customers. Taking into account the dimensions of certainty, response, reliability, empathy and tangibility as a result of experienced quality and expectations, the total deviation of the quality parameter in the scores is:

Kdeviation $=33193-34612=-1419$ 
Quality deviation signals the necessary changes within the company that shall be focused on improving customer service quality.

2. Consumers see a number of discrepancies when evaluating customer service quality through the criteria of expected and experienced quality.

3. Processes, technology and organizational culture have the greatest impact on the quality of customer service and corporate management. Taking into account the company's weaknesses, in order to develop corporate management to improve customer service quality the focus should be on contract-related processes, first-time customer service and working hours. The planning process should further explore and incorporate the technological elements related to the self-service website, the provision of promotional material and the accessibility of information provided by employees to users. The results of the qualitative study revealed that company management should pay more attention to the organizational culture that influences situations that reduce customer satisfaction such as: staff courtesy, staff responsiveness to customer needs, etc.

4. The overall assessment of the changes in customer service that have taken place is very good. The development of remote channels has had a great influence on customer service.

5. The technological elements that receive a lot of attention in the management of the company will have a strong influence on the quality of customer service in the last five years and in the future.

\section{REFERENCES}

1. Allio R. J. (2015). Good strategy makes good leaders. Strategy \& Leadership, Vol. 43 Issue: 5, p.3-9.

2. Alnawas I., Hemsley-Brown J. (2018) "The differential effect of cognitive and emotional elements of experience quality on the customer-service provider's relationship". International Journal of Retail \& Distribution Management, Vol. 46 Issue: 2, p .125-147.

3. Alsaggaf M.A., Althonayan A. (2018) An empirical investigation of customer intentions influenced by service quality using the mediation of emotional and cognitive responses. Journal of Enterprise Information Management, Vol. 35, Issue:1, p. 194-223.

4. Alzaydi Z. M., Al-Hajla A., Nguyen B., Jayawardhena C., (2018) "A review of service quality and service delivery: Towards a customer co-production and customerintegration approach". Business Process Management Journal, Vol. 24 Issue: 1, p. 295-328.

5. Babnik K., Breznik K., Dermol V., Širca N. T., (2014) "The mission statement: organisational culture perspective", Industrial Management \& Data Systems, Vol. 114 Issue: 4, p. 612-627

6. Bagozzi, R. P., Bergami, M., Marzocchi, G. L. and Morandin, G. (2012), "Customer - organization relationships: development and test of a theory of extended identities", Journal of Applied Psychology, Vol. 97 No. 1, p. 63-76.

7. Bakanauskas A. ir kt. (2011). Organizacijų vadyba. Vadovėlis. Kaunas: Vytauto Didžiojo universitetas.

8. Damkuvienè M., Petukienė A., Valuckienè J., Tijūnaitienė, Balčiūnas S., Bersėnaitė J. (2014). Klientu suvokiama dalyvavimo verte kaip organizacijos konkurencingumo didinimo veiksnys. Šiauliu universitetas: BMK leidykla.

(C) Birutė Petrošiene \& Rūta Ivanauskiene, 2019 
9. El-Manstrly, D. and Harrison, T. (2013), “ A critical examination of service loyalty measures",Journal of Marketing Management. doi: 10.1080/0267257X.2013.803139.

10. Hänninen N., Karjaluoto H., (2017). The effect of marketing communication on business relationship loyalty". Marketing Intelligence \& Planning, Vol. 35 Issue: 4, pp.458472.

11. Kazliūnas A. (2007). Kokybès vadyba. Vilnius: Mykolo Romerio universiteto Leidybos centras.

12. Liang, R. and Zhang, J. (2012), "The effect of service interaction orientation on customer satisfaction and behavioural intention. The moderating effect of dining frequency", Asia Pacific Journal of Marketing and Logistics, Vol. 24 No. 1, pp. 153-170.

13. McCrory B., Pilcher N., McMillan J., (2017) "A holistic framework to embed good company practice for customer retention", The TQM Journal, Vol. 29 Issue: 2, p.257-275

14. Norouziand M., Nahavandi B. The impact of commitment on customers' satisfaction with regard to the mediating role of employees and customers' friendly relationship(customers of bank melli in gilan province). [Žiūrèta 2018-01-20]. Prieiga per interneta: http://www.iioab.org/articles/IIOABJ_7.S4_1-6.pdf

15. Raišienè A. G., Vanagas R., Žuromskaitė B., Stasiukynas A., Dromantaitè A., Girčys A. P., Tamošiūnaitė R., Bileišis M. (2014). VEIKSMINGOS VADYBOS GAIRĖS: teorinès ¡žvalgos ir Lietuvos organizacijų atvejai. Vilnius: Mykolo Romerio universitetas.

16. Roy S., (2018) "Effects of customer experience across service types, customer types and time", Journal of Services Marketing. [žiūrèta 2018-04-04] Prieiga per internetą: http://www.emeraldinsight.com.ezproxy.vpu.lt/doi/pdfplus/10.1108/JSM-11-2016-0406

17. Sakalas A., Savanevičienè A., Girdauskienė L. (2016). Pokyčių valdymas. Vadovèlis. Kaunas: leidykla „Technologija“.

18. Smith J., Anderson S., Fox G., (2017). A quality system's impact on the service experience. International Journal of Operations \& Production Management, Vol. 37 Issue: 12, p.1817-1839.

19. Šimanskienès L. ir Župerkienè A. (2014). Darnus vadovavimas. Praktinis vadovas.Klaipėda: Klaipėdos universiteto leidykla.

20. Tamošiūnas A. (2013). Vadybos funkcijos ir priemonès. Vilnius: „Technika“.

21. Trkman P., Mertens W., Viaene S., Gemmel P., (2015). From business process management to customer process management. Business Process Management Journal, Vol. 21

22. Zakarevičius P. (2013). Vadybos paradigma. Organizaciju vadyba: sisteminiai tyrimai, Nr. 68.

23. Zhao Y., Yan L., Keh H.T., (2018) "The effects of employee behaviours on customer participation in the service encounter: The mediating role of customer emotions", European Journal of Marketing. [žiūrèta 2018-04-09] Prieiga per internetą: http://www.emeraldinsight.com.ezproxy.vpu.lt/doi/pdfplus/10.1108/EJM-10-2016-0559

ПЯТРОШЕНЕ БІРУТЕ - лектор, Маріямпольська колегія (Маріямполе, Литва)

E-mail: bir.petr@mkolegija.lt, ORCID ID: 0000-0002-5160-8249

IВАНАУСКЕНЕ РУТА - студентка програми «Бугалтерський облік», Маріямпольська колегія (Маріямполе, Литва)

E-mail: rut.ivan@mkolegija.lt, ORCID: 0000-0002-6877-6003

\section{РОЗВИТОК КОРПОРАТИВНОГО УПРАВЛІННЯ ДЛЯ ПОКРАЩЕННЯ ЯКОСТІ ОБСЛУГОВУВАННЯ КЛІЕНТІВ}

Анотація. В сучасному суспільстві всі компанії стикаються з постійними змінами, які викликають неспокої всередині компанії. Стимули, які здійснюють найбільший 
вплив на зміни, - це неочікувані коливання, які проявляються у зовнішньому середовищі. Одним 3 пріоритетних чинників, що має сильний вплив, є користувачі товарів і послуг, що надаються. Задоволеність клієнтів вважається одним 3 найбільш важливих чинників, що визначає успіх компанії. Компанії, які віддають пріоритет управлінню, зорієнтованому на користувачів послуг (товарів), що надаються, мають найбільші перспективи і переваги по відношенню до інших. У контексті корпоративної залежності від споживачів важливо забезпечити високоякісний i повністю удосконалений процес обслуговування клієнтів при одночасному покращенню корпоративного управління. Поставщиком енергії є компанія Energijos Skirstymo Operatorius AB (далі - ESO AB), що має більш 1,6 млн. клиєнтів, є домінуючою енергосервісною компанією у Литві. Домінуюча енергосервісна компанія дозволяє собі вносити непередбачувані чи незаплановані зміни у корпоративному управлінні, незалежно від якості і очікувань споживачів при оцінці якості обслуговування. 3 цих причин наукові, практичні, аналітичні дослідження якості обслуговування клієнтів у сфері надання державних послуг особливо $є$ актуальними i важливими. Одним iз найбільш важливих чинників як теоретичної, так і практичної діяльності компанії щодо надання послуг $є$ якість обслуговування клієнтів. Безперервні процеси покращення корпоративного управління незалежно від очікувань клієнтів створюють бар'єри для якості обслуговування клієнтів. Невідповідність між реальною і бажаною якістю обслуговування клієнтів створює недоліки в обслуговуванні клієнтів, що приводить до незадоволеності, недовіри і розчарування користувачів послуг і створює негативний імідж компанії на національному і міжнародному рівнях. 3 цих причин теоретичне i практичне питання про поточну реорганізацію управління компанією енергетичного сектору у сфері надання державних послуг щодо покращення якості обслуговування клієнтів залишається складним завданням. Мета дослідження - оцінити удосконалення управління, орієнтованого на якість обслуговування клієнтів у відповідності 3 теоретичними і практичними принципами управління. Об'єктом дослідження є система обслуговування клієнтів AB ESO. Завдання дослідження: визначити взаємозв'язок між обслуговуванням клієнтів та управління якістю, направленим на покращення управління компанією; проаналізувати основні і загальні елементи удосконалення менеджменту; оцінити реальну і очікувану якість обслуговування клієнтів ESO AB. Методи роботи - аналіз наукової літератури; аналіз документів; аналіз даних дослідження; анкетне опитування; графічне зображення.

Ключові слова: клієнт, якість обслуговування, людські ресурси, управління компанією, стратегія, престиж.

ПЯТРОШЕНЕ БИРУТЕ - лектор, Мариямпольская коллегия (Мариямполе, Литва)

E-mail: bir.petr@mkolegija.lt, ORCID ID: 0000-0002-5160-8249

ИВАНАУСКЕНЕ РУТА - студентка программы «Бухгалтерский учет», Мариямпольская коллегия (Мариямполе, Литва)

E-mail: rut.ivan@mkolegija.lt, ORCID: 0000-0002-6877-6003

\section{РАЗВИТИЕ КОРПОРАТИВНОГО УПРАВЛЕНИЯ ДЛЯ УЛУЧШЕНИЯ КАЧЕСТВА ОБСЛУЖИВАНИЯ КЛИЕНТОВ}

Аннотация. В современном обществе все компании сталкиваются с постоянными изменениями, которые вызывают волнения внутри компании. Стимулы, которые оказывают наибольшее влияние на изменения - это неожиданные колебания, которые обычно проявляються во внешней среде. Одним из приоритетных факторов, имеющих сильное влияние, являются пользователи предоставляемых товаров или услуг. Удовлетворенность клиентов считается одним из наиболее важных факторов, определяющим успех компании [14]. Компании, которые отдают приоритет 
управлению, ориентированному на пользователей предоставляемых услуг (товаров), имеют наибольшие перспективы и преимущества по отношению к другим. В контексте корпоративной зависимости от потребителей важно обеспечить высококачественный и полностью усовершенствованный процесс обслуживания клиентов при одновременном улучшении корпоративного управления. Поставщиком энергии является компания Energijos Skirstymo Operatorius AB (далее - ESO AB), имеющая более 1,6 млн. клиентов, является доминирующей энергосервисной компанией в Литве. Доминирующая энергосервисная компания часто позволяет себе вносить непредвиденные или незапланированные изменения в корпоративном управлении, независимо от качества и ожиданий потребителей при оценке качества обслуживания. По этим причинам научные, практические, аналитические исследования качества обслуживания клиентов в сфере предоставления государственных услуг особенно актуальны и значимы. Одним из наиболее важных факторов как теоретической, так и практической деятельности компании по предоставлению услуг является качество обслуживания клиентов. Непрерывные процессы по улучшению корпоративного управления независимо от ожиданий клиентов создают барьеры для качества обслуживания клиентов. Несоответствие между испытаннным и ожидаемым качеством обслуживания клиентов создает недостатки в обслуживании клиентов, что приводит к недовольству, недоверию и разочарованию пользователей услуг и создает негативный имидж компании на национальном и международном уровнях. По этим причинам практический и теоретический вопрос о том, основывается ли текущая реорганизация управления компанией энергетического сектора в сфере предоставления государственных услуг на улучшении качества обслуживания клиентов, остается сложной задачей. Цель исследования - оценить совершенствование управления, ориентированное на качество обслуживания клиентов в соответствии с теоретическими и практическими принципами управления. Объектом исследования является система обслуживания клиентов AB ESO. Задачи исследования: Определить взаимосвязь между обслуживанием клиентов и управлением качеством, направленным на улучшение управления компанией; представить основные и общие элементы совершенствования менеджмента; оценить испытанное и ожидаемое качество обслуживания клиентов ESO AB. Методы работы - анализ научной литературы; анализ документов; анализ данных исследования; анкетный опрос; графическое изображение.

Ключевые слова: клиент, качество обслуживания, человеческие ресурсы, управление компанией, стратегия, престиж.

Received date 12.09.2019

Accepted date 15.10.2019

Published date 20.11.2019

Developing corporate management to improve the quality of customer service 